\title{
Optimization of a digested sludge-derived mesoporous material as an efficient and stable heterogeneous catalyst for the photo-Fenton reaction
}

\author{
Shijie Yuan ${ }^{\dagger}$, Nianhua Liao ${ }^{\dagger}$, Bin Dong, Xiaohu Dai* \\ National Engineering Research Center for Urban Pollution Control, School of Environmental Science and Engineering, Tongji University, Shanghai \\ 200092, China
}

A R T I C L E I N F O

Article history:

Received 13 January 2016

Accepted 4 February 2016

Published 5 May 2016

Keywords:

Digested sludge

Iron-based compound

Mesoporous material

Heterogeneous photo-Fenton reaction

\begin{abstract}
A B S T R A C T
The anaerobic digestion of sludge has recently received increased interest because of the potential to transform organic matter into methane-rich biogas. However, digested sludge, the residue produced in that process, still contains high levels of heavy metals and other harmful substances that might make traditional disposal difficult. We have devised a facile method of converting digested sludge into a mesoporous material that acts as an effective and stable heterogeneous catalyst for the photo-Fenton reaction. A comparison of the removal of rhodamine B under different conditions showed that FAS-1-350, which was synthesized by mixing the digested sludge with a $1 \mathrm{~mol} / \mathrm{L}$ $\left(\mathrm{NH}_{4}\right)_{2} \mathrm{Fe}\left(\mathrm{SO}_{4}\right)_{2}$ solution followed by calcination at $350^{\circ} \mathrm{C}$, exhibited the best catalytic activity owing to its faster reaction rate and lower degree of Fe leaching. The results indicate that $\mathrm{Fe}^{2+}$-loaded catalysts have significant potential to act as stable and efficient heterogeneous promoters for the photo-Fenton reaction, with better performance than $\mathrm{Fe}^{3+}$-loaded catalysts because the $\mathrm{Fe}(\mathrm{II}) / \mathrm{Fe}(\mathrm{III})$ compounds formed in the calcination process are necessary to sustain the Fenton reaction. This protocol provides an alternative, environmentally friendly method of reusing digested sludge and demonstrates an easily synthesized mesoporous material that effectively degrades azo dyes.
\end{abstract}

(C) 2016, Dalian Institute of Chemical Physics, Chinese Academy of Sciences. Published by Elsevier B.V. All rights reserved.

\section{Introduction}

Sewage sludge, the residue produced by wastewater treatment processes, is regarded as a significant risk to the environment and human health and has recently become a growing concern [1-3]. Most sludge is disposed of in landfills, by incineration or agricultural reuse, all of which have numerous associated hazards, such as the presence of pathogens or metals [4-7]. Recently, there has been renewed interest in anaerobic digestion, one of the most widely used sludge treatment meth- ods, because of the ability of this technique to transform organic matter into methane-rich biogas $\left(60-70\right.$ vol\% $\left.\mathrm{CH}_{4}\right)$. Compared with traditional anaerobic digestion of low-solids sewage sludge, high-solids anaerobic digestion, which is characterized by feedstocks having a high content of total solids (TS, typically greater than $15 \mathrm{wt} \%$ ) [8], has several advantages. These include higher loadings, smaller reactor volumes, and lower energy consumption [9].

Biogas (a mixture of $\mathrm{CH}_{4}$ and $\mathrm{CO}_{2}$ ) is generated through the biodegradation of organic matter during anaerobic digestion.

\footnotetext{
*Corresponding author. Tel: +86-21-65986297; E-mail: daixiaohu@tongji.edu.cn

+ These authors contributed equally to this work.

This work was supported by the National Key Technology Research \& Development Program of China (2014BAL02B02) and the National Natural Science Foundation of China (51578397). 
However, tyrosine and tryptophan and their analogues, along with humic substances, are difficult to biodegrade [10]. In addition, although the bioavailability of heavy metals is increased to some extent after high-solids anaerobic digestion, the concentration of these metals is also increased [11], which can make traditional sludge disposal methods, such as incineration and agricultural reuse, difficult. The product of the anaerobic digestion of sewage sludge is known as digested sludge (DS), and this material retains refractory organic compounds, dead bacterial cells, and inorganic components in the form of various oxides and salts, in addition to Fe-based compounds.

The Fenton reaction is based on the transfer of electrons between $\mathrm{H}_{2} \mathrm{O}_{2}$ and metal ions, such as ferrous ions $\left(\mathrm{Fe}^{2+}\right)$, that act as catalysts [12]. Although they exhibit high degradation efficiency, traditional Fenton systems have several defects, such as $\mathrm{pH}$ limitations and iron precipitation. Despite these disadvantages, Fenton and photo-Fenton systems have proven to be efficient at hazardous waste remediation and water disinfection. In recent years, a variety of heterogeneous Fenton catalysts, including $\mathrm{Fe}_{2} \mathrm{O}_{3}, \mathrm{FeVO}_{4}$, and $\mathrm{BiFeO}_{3}$, have been applied to the degradation of organic contaminants [13-15], and many studies have been performed using various supports (zeolite, graphene oxide sheets, clays, carbons and resin) to enhance the efficiency of the heterogeneous Fenton process [16-18]. Unfortunately, many of these catalysts present leaching concerns and tend to produce high concentrations of Fe ions $[19,20]$ that are well above the European Union directives that allow only $0.0002 \%$ Fe in treated water transferred directly into the environment [21]. In light of this, it would be beneficial to develop a cost-effective, heterogeneous catalyst exhibiting high activity and long-term stability so as to obtain improved catalytic efficiency and a wider range of applications.

In a previous study, our group used sewage sludge as the raw ingredient for the facile synthesis of an effective and stable heterogeneous catalyst to promote the photo-Fenton reaction [20]. However, it was determined that a portion of the organic matter in the sludge (which could, alternatively, have been converted into biogas by advance anaerobic digestion) was either evaporated, combusted or carbonized during the calcination process. Therefore, to make more efficient use of the organic matter in the sewage sludge, we instead employed the less-useful DS to synthesize the catalysts. The refractory organic compounds, biomacromolecules and bacteria in DS can serve as scaffold templates for the preparation of a mesoporous material from sewage sludge. This may represent a more efficient and environmentally friendly way to use sewage sludge compared with energy generation via anaerobic digestion. The aim of the present study was to optimize the catalyst synthesis by varying the type of Fe-based salt, the concentration of iron compounds added and the calcination temperature.

\section{Experimental}

\subsection{Preparation of the catalysts}

The dewatered sewage sludge that was used for anaerobic digestion trials in this study was obtained from the Anting
Table 1

Parameters of dewatered sludge and digested sludge.

\begin{tabular}{lcr}
\hline Parameter & Dewatered sludge & Digested sludge \\
\hline $\mathrm{pH}$ & $7.31 \pm 0.15$ & $8.07 \pm 0.13$ \\
$\mathrm{TS}(\mathrm{wt} \%)$ & $16.50 \pm 0.03$ & $14.01 \pm 0.04$ \\
VS/TS (wt\%) & $58.83 \pm 0.04$ & $46.34 \pm 0.04$ \\
$\mathrm{TA}(\mathrm{mg} / \mathrm{L})$ & $5850.3 \pm 103.4$ & $15848.4 \pm 135.8$ \\
TAN (mg/L) & $759.9 \pm 35.2$ & $4120.7 \pm 112.1$ \\
\hline
\end{tabular}

TS: total solids; VS: volatile solids; TA: total alkalinity; TAN: total ammonia nitrogen.

Wastewater Treatment Plant in Shanghai, China (with a design capacity of $150000 \mathrm{~m}^{3} / \mathrm{d}$ ) [22]. The collected sludge was stored at $4{ }^{\circ} \mathrm{C}$ in preparation for daily feeding. An reactor with a working liquid volume of $6.0 \mathrm{~L}$ and equipped with helical stirring blades was operated at $60 \mathrm{r} / \mathrm{min}$, using repeated cycles composed of 2-min stirring and an 8-min break. The volumes of biogas generated in the reactor were measured with wet gas meters (XMF-1, China) on a daily basis. On the first day of the experimental trials, $6.0 \mathrm{~L}$ of seed sludge was added to the reactor, which was operated semi-continuously with a once daily draw-off and feeding at $35 \pm 1{ }^{\circ} \mathrm{C}$. During these trials, the reactor sludge retention time was on the order of $20 \mathrm{~d}$. The DS parameters were found to stabilize $60 \mathrm{~d}$ after starting the reactor operation, and so DS samples obtained between the 60 and 70 $\mathrm{d}$ marks were used to synthesize catalysts. The parameters of the dewatered sludge and the DS used in this study are summarized in Table 1.

All the organic and inorganic reagents used in this work were analytical grade unless otherwise stated. All solutions were prepared with water from a water purification system (Hitech Instrument Co., Shanghai, China).

The DS-derived, Fe-loaded mesoporous materials were prepared by adding $10 \mathrm{~g}$ DS to $20 \mathrm{ml}$ of various Fe-loading solutions followed by stirring for $3 \mathrm{~h}$ at room temperature. The Fe-loaded DS was subsequently separated by centrifugation and dried overnight in air at $105^{\circ} \mathrm{C}$. As a final step, the material was calcined in air for $3 \mathrm{~h}$.

Four Fe-based compounds, $\left(\mathrm{NH}_{4}\right)_{2} \mathrm{Fe}\left(\mathrm{SO}_{4}\right)_{2}$ (FAS), $\mathrm{FeSO}_{4}$ (FS), $\mathrm{FeCl}_{3}(\mathrm{FC})$ and $\mathrm{Fe}\left(\mathrm{NO}_{3}\right)_{3}(\mathrm{FN})$, were used. A DS sample was heated to $350{ }^{\circ} \mathrm{C}$ in a muffle furnace in air for $3 \mathrm{~h}$ to obtain the catalyst designated herein as DS-350, while the other samples are named based on the salt, the $\mathrm{Fe}(\mathrm{III}) / \mathrm{Fe}(\mathrm{II})$ concentration and the calcination temperature employed during the synthesis process. As an example, FS-1-350 indicates that the DS-derived, Fe-loaded mesoporous material was prepared by adding $10 \mathrm{~g}$ DS to $20 \mathrm{~mL}$ of a $1 \mathrm{~mol} / \mathrm{L} \mathrm{FeSO}_{4}$ solution followed by stirring for $3 \mathrm{~h}$ at room temperature, recovery via centrifugation, drying in air at $105{ }^{\circ} \mathrm{C}$ overnight, and finally calcination in air at $350{ }^{\circ} \mathrm{C}$ for $3 \mathrm{~h}$. Based on these same rules, the other samples are named FAS-1-350, FC-1-350, FN-1-350, and so on.

\subsection{Characterization of the sludge and the synthesized catalysts}

The TS, volatile solids (VS), total alkalinity (TA), and total ammonia nitrogen (TAN) contents of the dewatered sludge and DS were determined according to standard methods [23]. The 
elemental $\mathrm{C}, \mathrm{H}$, and $\mathrm{N}$ concentrations were measured using an elemental analyzer (Vario EL III, Hanau, Germany). The concentrations of heavy metals (iron included) in the catalysts were assessed by inductively coupled plasma atomic emission spectrometry (ICP, Agilent 720ES, USA) following microwave digestion in Teflon vessels using a mixture of $\mathrm{HNO}_{3}, \mathrm{HCl}$ and $\mathrm{HF}$. Fourier transform infrared (FTIR) spectra were obtained employing the $\mathrm{KBr}$ disk method with a VERTEX 70 FT-IR (Bruker Co., Bremen, Germany) to determine the functional groups present in the catalysts. The crystal structures of the samples were elucidated using X-ray diffraction (XRD, X' Pert PRO, Philips Co., Amsterdam, Netherlands). The morphology of each specimen was observed via scanning electron microscopy (SEM, FEI Co., Oregon, USA) and the surface areas were calculated with the Brunauer-Emmett-Teller method.

\subsection{Heterogeneous photo-Fenton degradation of $R h B$}

Rhodamine B (RhB), a widely used azo dye, was chosen as a model pollutant to evaluate the photo-catalytic activity of the synthesized catalysts. A $150-\mathrm{mL}$ portion of a $\mathrm{RhB}(55.5 \mathrm{mg} / \mathrm{L})$ solution was placed in a quartz glass cylinder $(8.5 \mathrm{~cm}$ high, 5.5 $\mathrm{cm}$ in diameter) with constant magnetic stirring and irradiated using a 30-W low-pressure mercury lamp affixed next to the cylinder. The reaction temperature was maintained at $25{ }^{\circ} \mathrm{C}$ during irradiation by employing an air conditioning unit.

In each degradation trial, $0.05 \mathrm{~g}$ of the synthesized catalyst was transferred into the reactor. Prior to the reaction, the suspension of the catalyst in the RhB solution was stirred under dark conditions for $30 \mathrm{~min}$ to fully disperse the catalyst, after which the $\mathrm{pH}$ of the reaction solution was adjusted to 4.00 , and a 1-mL portion of $3 \% \mathrm{H}_{2} \mathrm{O}_{2}$ was added to initiate the degradation reaction. At specific time intervals during the reaction, aliquots of the reaction solution were obtained and centrifuged at $4{ }^{\circ} \mathrm{C}$ immediately to remove any catalyst particles. The RhB concentration was subsequently measured using UV-vis spectroscopy (PhotoLab 6100, WTW Co., Germany) and the total organic carbon (TOC) concentration was determined using a TOC analyzer (TOC-L CPH CN 200, Shimadzu Co., Japan). The Fe concentration in each solution after irradiation was measured via ICP spectrometry to assess any leaching of Fe from the catalyst. Each trial was conducted in triplicate. To evaluate the stability and recyclability of the catalyst, the FAS-1-350 was recycled and reused six times, being employed to decompose the RhB under the same conditions each time.

\section{Results and discussion}

\subsection{Characterization of the synthesized catalysts}

The functional groups and the chemical bonds present on the catalyst surfaces were determined from their FTIR spectra (Fig. 1(a)).The peaks at 3451 and $1638 \mathrm{~cm}^{-1}$ are assigned to $\mathrm{O}-\mathrm{H}$ stretching and bending vibrations, respectively [24]. Compared with the sample treated solely by drying at $105^{\circ} \mathrm{C}$ [20], some peaks are seen to have disappeared. These include the $\mathrm{O} / \mathrm{N}-\mathrm{H}$ stretching vibration at $3298 \mathrm{~cm}^{-1}$, the $\mathrm{C}-\mathrm{H}$ stretch-
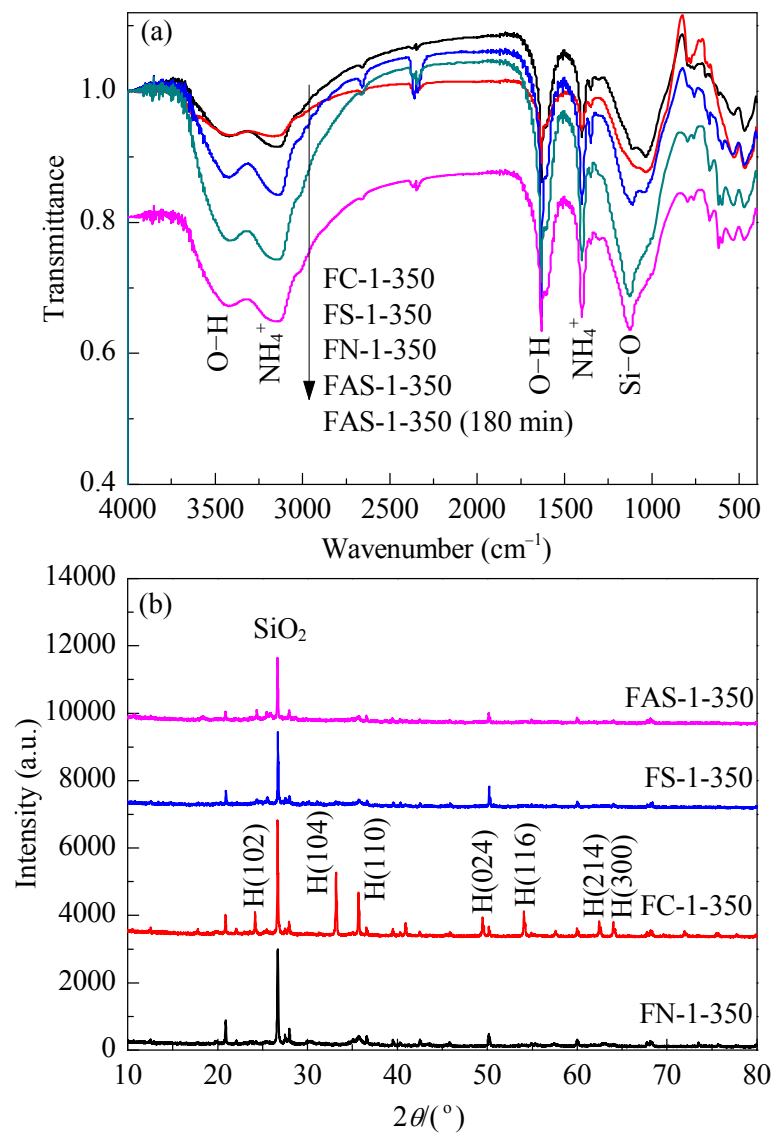

Fig. 1. FTIR spectra (a) and XRD patterns (b) of the synthesized catalysts.

ing vibrations from $\mathrm{CH}_{3}$ and $\mathrm{CH}_{2}$ groups at 2932 and $2852 \mathrm{~cm}^{-1}$, the $\mathrm{N}-\mathrm{H}$ deformation and $\mathrm{C}-\mathrm{N}$ stretching vibrations in $-\mathrm{CO}-\mathrm{NH}$ at $1541 \mathrm{~cm}^{-1}$ and the symmetrical $\mathrm{CH}_{2}$ deformations at 1442 $\mathrm{cm}^{-1}$, all of which are primarily attributed to the loss of adsorbed $\mathrm{H}_{2} \mathrm{O}$ and organic molecules and biomacromolecules that are evaporated, combusted or carbonized during the calcination process. The broad peak in the 1300 to $800 \mathrm{~cm}^{-1}$ region that is observed in all four spectra is actually composed of a set of peaks. The broad, high intensity band at $1080 \mathrm{~cm}^{-1}$ is ascribed to the asymmetric $\mathrm{Si}-\mathrm{O}-\mathrm{Si}$ stretching vibrations, the shoulder at $930 \mathrm{~cm}^{-1}$ corresponds to an $\mathrm{Si}-\mathrm{O}-\mathrm{Fe}$ linkage, and the $\mathrm{Si}-\mathrm{O}-\mathrm{Si}$ symmetrical stretching vibration is assigned to the peak at $800 \mathrm{~cm}^{-1}$ [25]. Additional peaks at 475 and $671 \mathrm{~cm}^{-1}$, characteristic of the symmetric stretching and bending vibrations of the Si-O-Fe moiety [26], further confirm the formation of chemical bonds between the $\mathrm{SiO}_{2}$ in the DS and the loaded $\mathrm{Fe}$ compound in the synthesized catalysts. Compared with catalysts made with dewatered sewage sludge [20], new peaks are evident at 3150 and $1400 \mathrm{~cm}^{-1}$, attributed to $\mathrm{NH}_{4}^{+}$stretching and antisymmetric bending vibrations, respectively. Ammonium is a product of the anaerobic digestion of DS and may reach a concentration as high as $4000 \mathrm{mg} / \mathrm{L}$ in the digestion mixture [22], thus this process may account for the appearance of the $\mathrm{NH}_{4}^{+}$peaks. After six recycling trials involving the degradation of RhB, the FTIR spectra of the FAS-350-1 do not show significant changes, demonstrating the stability of the catalyst. 
Table 2

Element concentrations (wt\%) of the synthesized catalysts.

\begin{tabular}{lccccc}
\hline Element & DS-350 & FN-1-350 & FC-1-350 & FS-1-350 & FAS-1-350 \\
\hline $\mathrm{C}$ & $0.78 \pm 0.10$ & $0.73 \pm 0.08$ & $1.06 \pm 0.06$ & $0.97 \pm 0.08$ & $0.59 \pm 0.03$ \\
$\mathrm{~N}$ & $0.29 \pm 0.05$ & $0.15 \pm 0.01$ & $0.32 \pm 0.03$ & $0.28 \pm 0.02$ & $0.27 \pm 0.01$ \\
$\mathrm{H}$ & $1.62 \pm 0.06$ & $1.16 \pm 005$ & $0.91 \pm 0.01$ & $1.48 \pm 0.04$ & $1.72 \pm 0.07$ \\
$\mathrm{Fe}$ & $10.76 \pm 0.57$ & $18.05 \pm 0.98$ & $18.78 \pm 1.62$ & $20.76 \pm 1.16$ & $0.38 \pm 0.01$ \\
$\mathrm{Al}$ & $0.44 \pm 0.03$ & $0.40 \pm 0.03$ & $0.40 \pm 0.04$ & $0.19 \pm 0.01$ & $0.41 \pm 0.02$ \\
$\mathrm{Ca}$ & $0.17 \pm 0.02$ & $0.09 \pm 0.01$ & $0.19 \pm 0.03$ & $0.03 \pm 0.006$ & $0.20 \pm 0.02$ \\
$\mathrm{Cr}$ & $0.05 \pm 0.004$ & $0.05 \pm 0.007$ & $0.05 \pm 0.01$ & $0.03 \pm 0.002$ & $0.06 \pm 0.01$ \\
$\mathrm{Cu}$ & $0.02 \pm 0.003$ & $0.02 \pm 0.001$ & $0.04 \pm 0.007$ & $0.04 \pm 0.008$ & $0.06 \pm 0.002$ \\
$\mathrm{Mg}$ & $0.11 \pm 0.01$ & $0.02 \pm 0.003$ & $0.03 \pm 0.008$ & $0.09 \pm 0.006$ & $0.12 \pm 0.007$ \\
$\mathrm{Mn}$ & $0.03 \pm 0.001$ & $0.11 \pm 0.009$ & $0.09 \pm 0.003$ & $0.31 \pm 0.02$ & $0.41 \pm 0.03$ \\
$\mathrm{Na}$ & $0.47 \pm 0.03$ & $0.44 \pm 0.04$ & $0.35 \pm 0.01$ & $0.02 \pm 0.003$ & $0.04 \pm 0.002$ \\
$\mathrm{Ni}$ & $0.02 \pm 0.005$ & $0.02 \pm 0.004$ & $0.03 \pm 0.007$ & $0.006 \pm 0.001$ & $0.008 \pm 0.002$ \\
$\mathrm{~Pb}$ & $0.004 \pm 0.001$ & $0.005 \pm 0.001$ & $0.008 \pm 0.001$ & $0.12 \pm 0.01$ & $0.26 \pm 0.02$ \\
$\mathrm{Zn}$ & $0.07 \pm 0.01$ & $0.07 \pm 0.02$ & $0.18 \pm 0.03$ & &
\end{tabular}

XRD was used to characterize the structure of the synthesized catalysts (Fig. 1(b)). Quartz $\left(\mathrm{SiO}_{2}\right)$, with two main characteristic peaks at $2 \theta=20.9^{\circ}$ and $26.6^{\circ}$, was the most recognizable crystallographic structure in the pattern of each material $[27,28]$. The FC-1-350 generated three main diffraction peaks at $2 \theta=33.1^{\circ}, 35.6^{\circ}$, and $50.1^{\circ}$, which are assigned to the (104), (110), and (024) reflections of $\alpha-\mathrm{Fe}_{2} \mathrm{O}_{3}$ (hematite) (JCPDS 84-0306). No obvious characteristic diffraction peak of $\alpha-\mathrm{Fe}_{2} \mathrm{O}_{3}$ (hematite) was observed in the FAS-1-350, FS-1-350, or FN-1-350 patterns. These XRD results suggest that the FC-1-350 consisted mainly of $\alpha-\mathrm{Fe}_{2} \mathrm{O}_{3}$ and $\mathrm{SiO}_{2}$ crystallites, whereas the FAS-1-350, FS-1-350, and FN-1-350 were composed primarily of $\mathrm{SiO}_{2}$ crystallites and amorphous iron. However, the Fe concentrations in these catalysts as determined by ICP spectrometry (Table 2) were similar, ranging from (18.05 \pm $0.98) \%$ to $(20.76 \pm 1.16) \%$ ((18.05 \pm 0.98$) \%$ for FN-1-350, $(18.78 \pm 1.62) \%$ for FC-1-350, (20.76 \pm 1.16$) \%$ for FS-1-350, and $(19.15 \pm 2.29) \%$ for FAS-1-350). It is therefore evident that both crystalline and amorphous iron can play significant roles in the synthesized catalysts during photo-Fenton degradation $[29,30]$.

The surface morphologies of the synthesized catalysts are
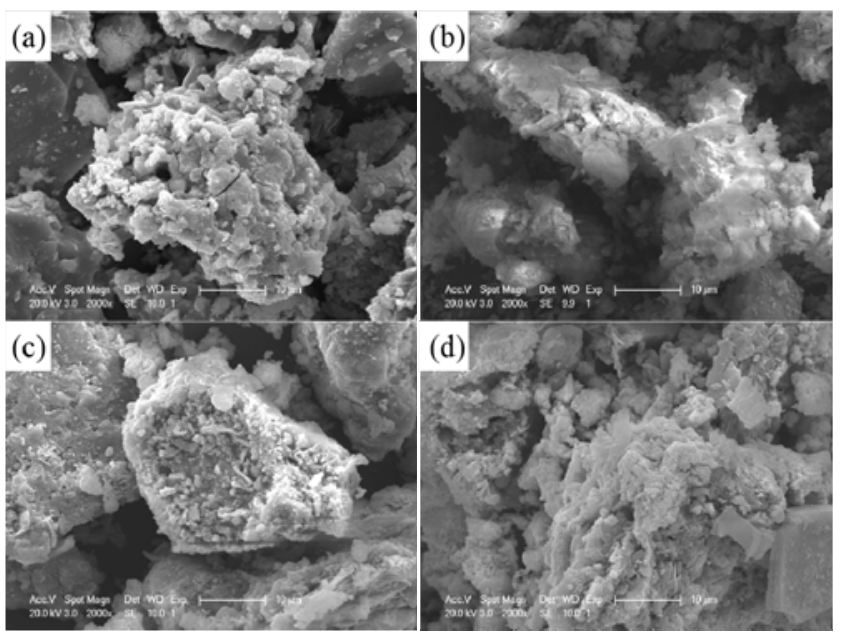

Fig. 2. SEM images of (a) FAS-1-350, (b) FC-1-350, (c) FN-1-350 and (d) FS-1-350. shown in Fig. 2. The coarse, porous surfaces seen here are due to the evaporation or decomposition of $\mathrm{H}_{2} \mathrm{O}$ molecules and organic molecules during the calcination process. The $\mathrm{N}_{2}$ adsorption-desorption results for the catalysts are presented in Fig. 3. According to the IUPAC classification system, all of the isotherms were type IV and are thus typical of large-pore mesoporous solids. The sample surface areas, pore volumes, and pore sizes are summarized in Table 3. Compared with the FC-1-350 and FN-1-350, the FAS-1-350 and FS-1-350 displayed porous structures that increased their surface areas and pore volumes without generating changes in the pore size. All of these data (Table 3 and Fig. 2) demonstrate that the $\mathrm{Fe}^{2+}$-loaded catalysts provided a larger contact area and thus had greater potential to act as stable, efficient heterogeneous catalysts for the photo-Fenton reaction compared with the $\mathrm{Fe}^{3+}$-loaded catalysts. It is also evident that the FAS-1-350 may exhibit the best catalytic activity.

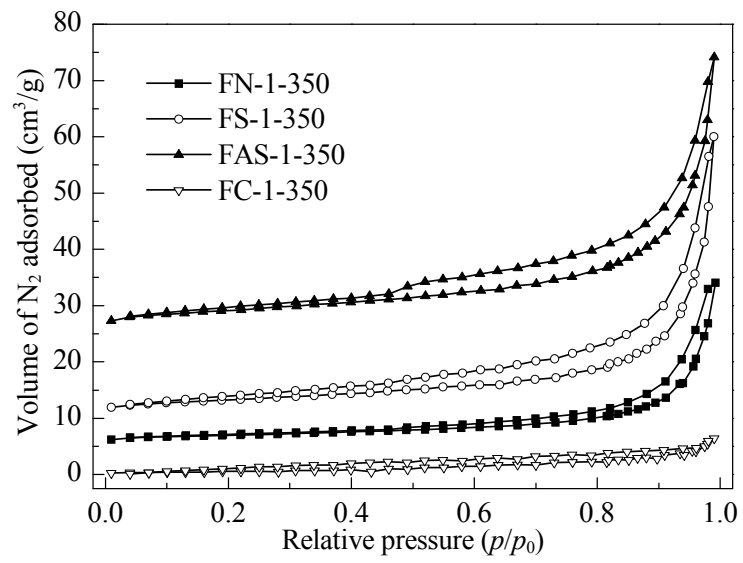

Fig. 3. $\mathrm{N}_{2}$ adsorption-desorption isotherms of the synthesized catalysts.

Table 3

Textural properties of the synthesized catalysts.

\begin{tabular}{lccc}
\hline Catalyst & $\begin{array}{c}\text { Specific surface } \\
\text { area }\left(\mathrm{m}^{2} / \mathrm{g}\right)\end{array}$ & $\begin{array}{c}\text { Pore volume } \\
\left(\mathrm{cm}^{3} / \mathrm{g}\right)\end{array}$ & $\begin{array}{c}\text { Pore diameter } \\
(\mathrm{nm})\end{array}$ \\
\hline FN-1-350 & 4.21 & 0.010 & 22.39 \\
FC-1-350 & 6.96 & 0.045 & 25.85 \\
FS-1-350 & 11.86 & 0.077 & 26.09 \\
FAS-1-350 & 15.17 & 0.076 & 20.04 \\
\hline
\end{tabular}




\subsection{Photo-Fenton degradation of $R h B$}

To obtain information regarding the transformation of the structural and molecular features of RhB during the degradation process, ultraviolet (UV)-visible spectra of a typical degradation process were acquired during UV irradiation of a reaction solution composed of $\mathrm{RhB}$ with both $\mathrm{H}_{2} \mathrm{O}_{2}$ and FAS-1-350 (Fig. 4(a)). The RhB absorption band in the aqueous solution is seen at $547 \mathrm{~nm}$, and its intensity reflects the RhB concentration in the solution. Rapid RhB degradation is clearly seen by the eventual disappearance of this peak within 20 min. Approximately $69 \%$ TOC reduction was determined for the same solution at the 30 min mark, suggesting that the FAS-1-350 catalyst resulted in a significant degree of RhB mineralization. A UV-visible spectrum of a blank solution (with FAS-1-350 and stirring but without UV irradiation, tracked for $150 \mathrm{~min}$ ) indicated that very little dye is removed by physical adsorption.

The stability of the FAS-350-1 under UV irradiation was also assessed as a means of examining the practical applicability of this catalyst (Fig. 4(b)). No obvious deactivation of the FAS-350-1 catalyst was observed over six repetitive trials, indicating its excellent long-term stability.

To optimize the DS-derived mesoporous material, RhB removal was assessed under different conditions, with the data shown in Fig. 5(a) and (b). The linear relationship of $\ln \left(C_{t} / C_{0}\right)$ versus $t$ demonstrates that RhB degradation under different photo-Fenton conditions followed pseudo-first-order kinetics as in the equation: $\ln \left(C_{t} / C_{0}\right)=-k t$, where $C_{t} / C_{0}$ is the normalized $\mathrm{RhB}$ concentration, $t$ is the reaction time ( $\mathrm{min})$, and $k$ is the reaction rate constant $\left(\mathrm{min}^{-1}\right)$.

RhB removal was also observed when employing the FAS-1-350 and FS-1-350 (Fig. 5(a)). The values of $k$ for RhB during the degradation processes with various Fe-loaded mesoporous materials present were: FAS-1- $T>$ FS-1- $T>$ FN-1- $T>$ FC-1- $T$, where $T$ represents the synthesized catalysts calcined in air at a given temperature. As an example, the $k$ values for RhB during the degradation processes with the FAS-1-350, FS-1-350, FN-1-350, and FC-1-350 were 0.308 $\pm 0.016,0.282 \pm$ $0.005,0.094 \pm 0.008$, and $0.078 \pm 0.009 \mathrm{~min}^{-1}$, respectively. The $k$ for RhB during the degradation processes with specific catalysts (FAS, for instance) that were calcined in air at different temperatures were FAS-1-350 (0.308 $\left.\pm 0.016 \mathrm{~min}^{-1}\right)>$ FAS-1-250 $\left(0.183 \pm 0.009 \mathrm{~min}^{-1}\right)>$ FAS-1-450 $(0.130 \pm 0.022$ $\left.\mathrm{min}^{-1}\right)>$ FAS- $1-550\left(0.118 \pm 0.021 \mathrm{~min}^{-1}\right)>$ FAS- $1-650(0.070 \pm$ $\left.0.008 \mathrm{~min}^{-1}\right)>$ FAS-1-750 $\left(0.056 \pm 0.006 \mathrm{~min}^{-1}\right)$. It is likely that a higher calcination temperature will remove a greater proportion of the organic/inorganic matter in the DS, resulting in damage to the scaffold template of the synthesized catalyst, whereas an overly low temperature will not be able to form a good scaffold. Therefore, the FM-1-350 (especially the FAS-1-350) exhibited the fastest reaction rates, followed by the FM-1-250, FM-1-450, FM-1-550, FM-1-650, and FM-1-750 (where FM indicates FAS/FS/FC or FN).

Figure 5(b) summarizes the RhB $k$ values measured during typical degradation processes with FAS or FS materials at different concentrations (FAS/FS-C-350). When the FAS or FS amount was increased from 0.5 to $3 \mathrm{~mol} / \mathrm{L}$, the $k$ increased
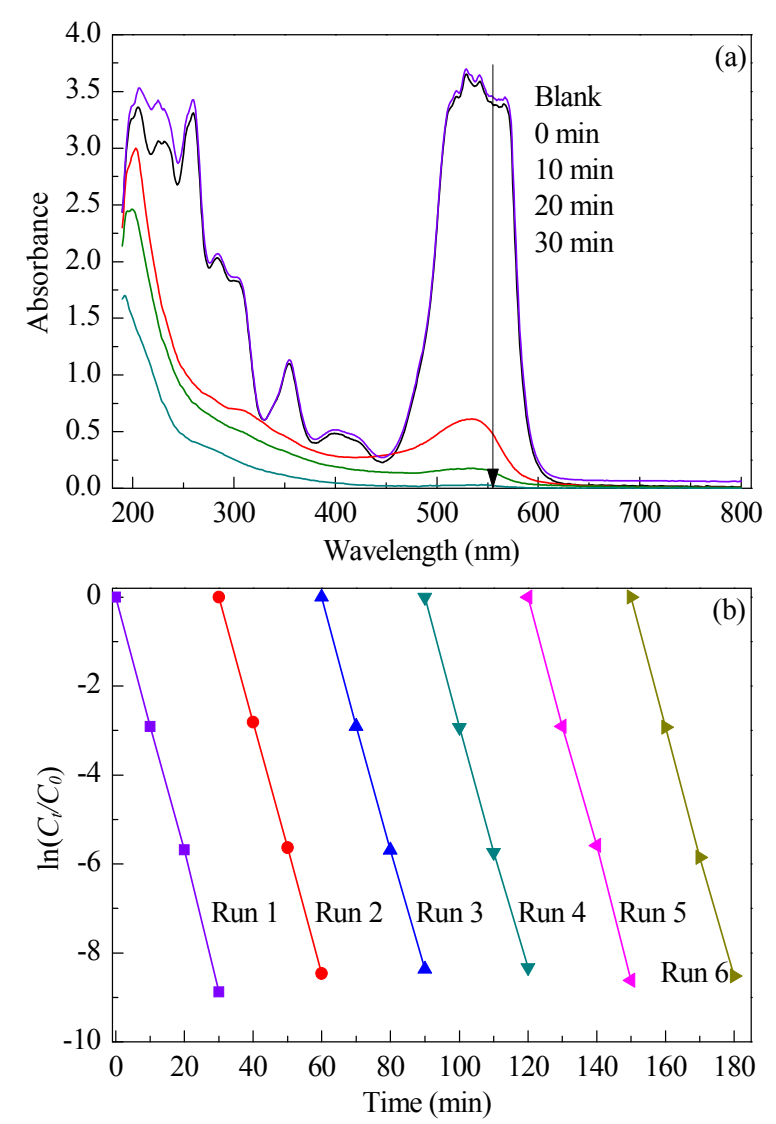

Fig. 4. (a) UV-visible spectra of a typical RhB degradation process under UV irradiation with the addition of both $\mathrm{H}_{2} \mathrm{O}_{2}$ and FAS-1-350; (b) Repeated $\mathrm{RhB}$ degradation trials under UV irradiation with addition of both $\mathrm{H}_{2} \mathrm{O}_{2}$ and FAS-1-350.

from $0.149 \pm 0.013$ to $1.888 \pm 0.284 \mathrm{~min}^{-1}$, and from $0.134 \pm$ 0.013 to $4.195 \pm 0.714 \mathrm{~min}^{-1}$, respectively. At the same time, the respective Fe concentration (wt \%) of the synthesized catalysts increased from $(17.85 \pm 2.33)$ to $(24.76 \pm 2.99)$ wt $\%$ and from $(19.43 \pm 2.54)$ to $(29.64 \pm 3.38)$ wt $\%$, respectively (Fig. $5(d))$. The Fe concentrations in the solution after irradiation were $0.20 \pm 0.13$ and $0.94 \pm 0.24 \mathrm{mg} / \mathrm{L}$, respectively, with initial FAS concentrations of 0.5 and $1 \mathrm{~mol} / \mathrm{L}$, whereas they rapidly increased to $3.10 \pm 0.40$ and $10.58 \pm 1.41 \mathrm{mg} / \mathrm{L}$, respectively, when the initial FAS concentration reached 1.5 and $3 \mathrm{~mol} / \mathrm{L}$ (Fig. 5(c)). Since the Fe concentrations in the solution after the degradation of $\mathrm{RhB}$ (over $20 \mathrm{~min}$ ) increased rapidly when the initial FS concentration was $1.5 \mathrm{~mol} / \mathrm{L}$, it appears that a 1 mol/L concentration may be the best initial Fe-loading level with regard to avoiding significant leaching. Given its faster reaction rate (see Fig. 5(a) and (b)) and lesser degree of Fe leaching (Fig. 5(c)), the FAS-1-350 exhibits the best catalytic activity with a sustainable amount of Fe leaching, in good agreement with the earlier characterization data for the synthesized catalysts.

\subsection{Possible reaction mechanism}

Based on the results above, we propose a possible mechanism associated with the functioning of Fe-based heterogene- 

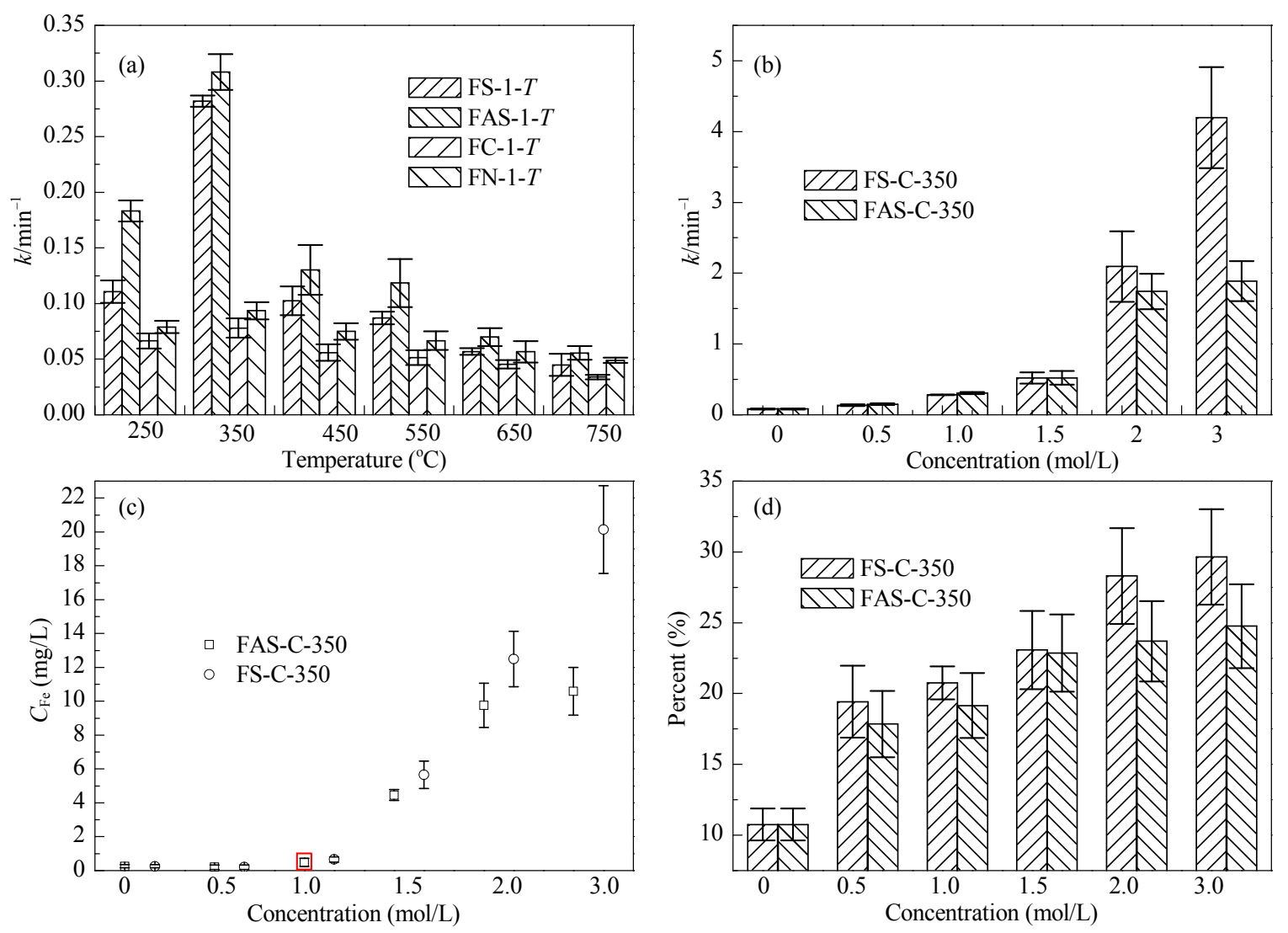

Fig. 5. Catalytic activity and Fe leaching of the synthesized catalysts. (a) The reaction rate constant of RhB during typical degradation processes under various conditions (Fe type and temperature); (b) The reaction rate constant of RhB during typical degradation processes at different Fe concentrations; (c) Fe concentrations in solution after the photo-Fenton degradation of RhB (the red square indicates data for the FAS-1-350, which exhibited the best catalytic activity with sustainable Fe leaching); (d) Fe concentrations (wt\%) of the synthesized catalysts.

ous catalysts during the degradation of RhB. Initially, both the $\mathrm{RhB}$ and $\mathrm{H}_{2} \mathrm{O}_{2}$ are adsorbed on the surface of the iron catalyst. Subsequently, the $\mathrm{Fe}(\mathrm{II}) / \mathrm{Fe}$ (III) redox system on the catalyst surface is initiated in conjunction with the $\mathrm{H}_{2} \mathrm{O}_{2}$ to produce $\cdot \mathrm{OH}$ radicals capable of oxidizing the organic dye into various intermediates and, eventually, non-toxic inorganic species. Moreover, the Fe(II)/Fe(III) redox cycle is enhanced by UV light irradiation, resulting in markedly accelerated degradation of the RhB [31,32]. Eventually, the adsorbed RhB molecules are converted into $\mathrm{CO}_{2}$ and $\mathrm{H}_{2} \mathrm{O}$ by the $\cdot \mathrm{OH}$ radicals on the surface of the catalyst, while the catalyst itself is restored to its original state [33]. The reactions in this heterogeneous system can be expressed as follows.

$$
\begin{aligned}
\text { DS-Fe(II) }+\mathrm{H}_{2} \mathrm{O}_{2} & \rightarrow \text { DS-Fe(III) }+\cdot \mathrm{OH}^{+} \mathrm{OH}^{-} \\
\text {DS-Fe(III) }+\mathrm{H}_{2} \mathrm{O}_{2} & \rightarrow \mathrm{DS}-\mathrm{Fe}(\mathrm{II})+\mathrm{HO}_{2} \cdot+\mathrm{H}^{+} \\
\mathrm{DS}-\mathrm{Fe}(\mathrm{II})+\mathrm{HO}_{2}+\mathrm{H}^{+} & \rightarrow \mathrm{DS}-\mathrm{Fe}(\mathrm{III})+\mathrm{H}_{2} \mathrm{O}_{2} \\
\mathrm{DS}-\mathrm{Fe}(\mathrm{III})+\mathrm{HO}_{2} \cdot & \rightarrow \mathrm{DS}-\mathrm{Fe}(\mathrm{II})+\mathrm{O}_{2}+\mathrm{H}^{+} \\
\mathrm{H}_{2} \mathrm{O}_{2}+\cdot \mathrm{OH}^{+} & \rightarrow \mathrm{HO}_{2} \cdot+\mathrm{H}_{2} \mathrm{O} \\
\text { DS-Fe(III) }+\mathrm{H}_{2} \mathrm{O}+h v & \rightarrow \text { DS-Fe(II) }+\mathrm{HO} \cdot+\mathrm{H}^{+} \\
\mathrm{HO} \cdot+\mathrm{RhB} & \rightarrow \text { degradation products }
\end{aligned}
$$

The Fenton reaction is sustained by the redox recycling of the $\mathrm{Fe}(\mathrm{II}) / \mathrm{Fe}(\mathrm{III})$ couple. Although Fe(III) can also initiate a Fenton-like reaction [34], the reduction of $\mathrm{Fe}^{3+}$ to $\mathrm{Fe}^{2+}$ occurs much more slowly than the reverse process [35]. Thus, the addition of Fe(II) to the DS-derived catalysts allows the for- mation of $\mathrm{Fe}(\mathrm{II}) / \mathrm{Fe}(\mathrm{III})$ compounds during the calcination process. Interestingly, much less Fe(II) is formed in this process when $\mathrm{Fe}^{3+}$ is added to the DS-derived catalysts. This may represent the reason why the $\mathrm{Fe}^{2+-}$-loaded catalysts are better able to act as stable and efficient heterogeneous catalysts for the photo-Fenton reaction compared with $\mathrm{Fe}^{3+}$-loaded catalysts.

\subsection{Significance in application}

The reaction rate constant for the Fenton reaction was reduced along with the mesoporous quality of the catalyst, an effect that was attributed to the evaporation, combustion, or carbonization of adsorbed $\mathrm{H}_{2} \mathrm{O}$, small organic molecules, and biomacromolecules in the DS during the calcination process. The original Fe content (10.07 mg/g dry material, Table 2) in the DS is evidently able to provide catalytic sites in addition to the added iron species. These properties make DS a useful raw ingredient for the synthesis of an efficient and stable catalyst $[1,36,37]$. Based on this study, more efficient use of sewage sludge could be achieved by employing the anaerobic digestion process to generate biogas from biodegradable organic matter and then applying the remaining DS (with less useful organic compounds and even more heavy metals and ferrous compounds) as an environmentally friendly material for the synthesis of Fe-based catalysts. 
This work demonstrated the synthesis of an efficient photo-Fenton catalyst composed of a mesoporous material derived from DS via a facile method consisting of only three steps (stirring, centrifugation and heating). The surface area of the synthesized catalyst was relatively low compared with those of catalysts prepared by other reported methods, such as carbonization, chemical activation, and pyrolysis [38]. However, these other methods would be accompanied by an unavoidable cost increase and greater investment for equipment. Because of its ample supply and simple synthesis method, the DS-derived catalyst should lead to savings in operational costs and less investment for equipment, and thus may be more acceptable for practical applications and from an environmental standpoint.

\section{Conclusions}

A more environmentally friendly process was developed by using DS rather than sewage sludge in the synthesis of an Fe-loaded mesoporous material. Several DS-derived catalysts were synthesized via a facile method, and their efficiency and stability as heterogeneous catalysts for the photo-Fenton reaction were demonstrated. The results indicate that the $\mathrm{Fe}^{2+}$-loaded versions have more potential to act as stable and efficient heterogeneous catalysts for the photo-Fenton reaction than the $\mathrm{Fe}^{3+}$-loaded specimens. Of the synthesized catalysts tested in the present work, the faster reaction rate and lower Fe leaching of the FAS-1-350 indicate that it exhibits the best catalytic activity.

\section{References}

[1] K. McClellan, R. U. Halden, Water Res., 2010, 44, 658-668.

[2] S. Werle, R. K. Wilk, Renew. Energy, 2010, 35, 1914-1919.

[3] Q. L. Xie, P. Peng, S. Y. Liu, M. Min, Y. L. Cheng, Y. Q. Wan, Y. Li, X. Y.
Lin, Y. H. Liu, P. Chen, R. Ruan, Bioresour. Technol., 2014, 172, 162-168.

[4] O. Malerius, J. Werther, Chem. Eng. J., 2003, 96, 197-205.

[5] D. Fytili, A. Zabaniotou, Renew. Sust. Energy Rev., 2008, 12, 116-140.

[6] M. Lundin, M. Olofsson, G. J. Pettersson, H. Zetterlund, Resour. Conserv. Recycl., 2004, 41, 255-278.

[7] G. Ahlberg, O. Gustafsson, P. Wedel, Environ. Pollut., 2006, 144, 545-553.

[8] J. Rapport, R. Zhang, B. M. Jenkins, R. B. Williams eds., Current Anaerobic Digestion Technologies Used for Treatment of Municipal Organic Solid Waste, California Integrated Waste Management Board, California Environmental Protection Agency, Sacramento, CA, 2008.

[9] X. H. Dai, X. Gai, B. Dong, Bioresour. Technol., 2014, 174, 6-10.

[10] X. W. Li, X. H. Dai, J. Takahashi, N. Li, J. W. Jin, L. L. Dai, B. Dong, Bioresour. Technol., 2014, 159, 412-420.

[11] B. Dong, X. G. Liu, L. L. Dai, X. H. Dai, Bioresour. Technol., 2013, 131, 152-158.

[12] E. Neyens, J. Baeyens, J. Hazard. Mater., 2003, 98, 33-50.

[13] J. Bandara, U. Klehm, J. Kiwi, Appl. Catal. B, 2007, 76, 73-81.

[14] J. H. Deng, J. H. Jiang, Y. Y. Zhang, X. D. Lin, C. M. Du, Y. Xiong, Appl. Catal. B, 2008, 84, 468-473.

[15] W. Luo, L. H. Zhu, N. Wang, H. Q. Tang, M. J. Cao, Y. B. She, Environ. Sci. Technol., 2010, 44, 1786-1791.

[16] M. L. Rache, A. R. García, H. R. Zea, A. M. T. Silva, L. M. Madeira, J. H. Ramírez, Appl. Catal. B, 2014, 146, 192-200.

[17] Y. J. Yao, Y. M. Cai, F. Lu, F. Y. Wei, X. Y. Wang, S. B. Wang, J. Hazard. Mater., 2014, 270, 61-70.

[18] S. Guo, G. K. Zhang, Y. D. Guo, J. C. Yu, Carbon, 2013, 60, 437-444.

[19] C. Adán, A. Martinez-Arias, S. Malato, A. Bahamonde, Appl. Catal. B, 2009, 93, 96-105.

[20] S. J. Yuan, X. H. Dai, Appl. Catal. B, 2014, 154-155, 252-258.

[21] S. Sabhi, J. Kiwi, Water Res., 2001, 35, 1994-2002.

[22] N. N. Duan, B. Dong, B. Wu, X. H. Dai, Bioresour. Technol., 2012, 104, 150-156.

[23] L. S. Clesceri, A. E. Greenberg, A. D. Eaton eds., Standard Methods for the Examination of Water and Wastewater, 20th ed., American

\section{Graphical Abstract}

Chin. J. Catal., 2016, 37: 735-742 doi: 10.1016/S1872-2067(15)61066-X

Optimization of a digested sludge-derived mesoporous material as an efficient and stable heterogeneous catalyst for the photo-Fenton reaction

Shijie Yuan, Nianhua Liao, Bin Dong, Xiaohu Dai*

Tongji University

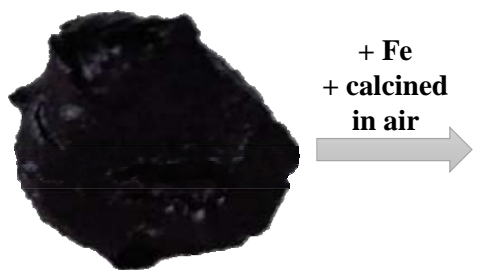

Digested sludge

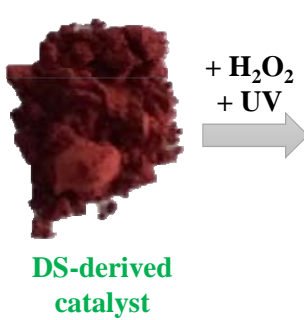

catalyst

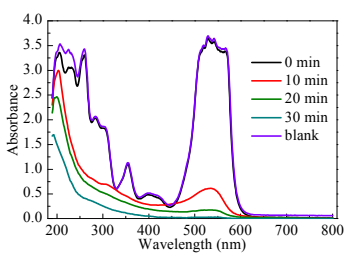

FAS-1-350 exhibits the best catalyst activity

Digested sludge-derived photo-Fenton catalysts were synthesized via a facile three-step method. The catalyst produced using ferrous ammonium sulfate in conjunction with a calcination temperature of $350{ }^{\circ} \mathrm{C}$ exhibits the best catalytic activity because of its faster reaction rate and lower Fe leaching. 
Public Health Association, Washington, DC, 1998.

[24] J. Schmitt, H. C. Flemming, Int. Biodeter. Biodegr., 1998, 41, 1-11.

[25] E. Doelsch, A. Masion, J. Rose, W. E. E. Stone, J. Y. Bottero, P. M. Bertsch, Colloid Surface A, 2003, 217, 121-128.

[26] I. Moriguchi, M. Honda, T. Ohkubo, Y. Mawatari, Y. Teraoka, Catal. Today, 2004, 90, 297-303.

[27] J. N. Zhang, F. Lu, H. Zhang, L. M. Shao, D. Z. Chen, P. J. He, Sci. Rep., 2015, 5, 9406.

[28] J. Y. Feng, X. J. Hu, P. L. Yue, Environ. Sci. Technol., 2004, 38, 269-275.

[29] S. Guo, G. K. Zhang, J. C. Yu, J. Colloid Interf. Sci,, 2015, 448, 460-466.

[30] F. Martínez, G. Calleja, J. A. Melero, R. Molina, Appl. Catal. B, 2007, $70,452-460$.
[31] M. M. Cheng, W. J. Song, W. H. Ma, C. C. Chen, J. C. Zhao, J. Lin, H. Y. Zhu, Appl. Catal. B, 2008, 77, 355-363.

[32] W. J. Song, M. M. Cheng, J. H. Ma, W. H. Ma, C. C. Chen, J. C. Zhao, Environ. Sci. Technol., 2006, 40, 4782-4787.

[33] Y. W. Gao, Y. Wang, H. Zhang, Appl. Catal. B, 2015, 178, 29-36.

[34] D. B. Hasan, A. R. Abdul Aziz, W. M. A. W. Daud, Chem. Eng. Res. Des., 2012, 90, 298-307.

[35] C. Wang, H. Liu, Z. M. Sun, Int. J. Photoenergy, 2012, 2012, 801694.

[36] E. Viau, K. Bibby, T. Paez-Rubio, J. Peccia, Environ. Sci. Technol., 2011, 45, 5459-5469.

[37] M. A. Shannon, P. W. Bohn, M. Elimelech, J. G. Georgiadis, B. J. Marinas, A. M. Mayes, Nature, 2008, 452, 301-310.

[38] A. Ros, M. A. Montes-Moran, E. Fuente, D. M. Nevskaia, M. J. Martin, Environ. Sci. Technol., 2006, 40, 302-309.

\title{
消化污泥负载稳定高效非均相光 Fenton 催化材料的制备及性能优化
}

\author{
院士杰”，廖年华 ${ }^{\dagger}$, 董 滨, 戴晓虎 ${ }^{*}$ \\ 同济大学环境科学与工程学院城市污染控制国家工程研究中心, 上海 200092
}

摘要: 近年来, 随着我国经济飞速发展和城市人口快速增长, 城市污水排放量不断增加, 市政污泥产生量也随之增大. 市政 污泥含有大量有毒有害物质, 如寄生虫卵、致病菌、有机污染物和重金属等, 若不进行妥善处理处置将会对环境造成严重 的二次污染. 传统的污泥处理处置方法如卫生填埋、露天堆放和土地利用等已经无法满足日趋严格的污泥处理处置标准, 研发新的污泥资源化利用方法具有重要的环境意义和经济价值.

本课题组前期以铁盐为前驱体通过简单步骤制备了以市政污泥为载体, 污泥中的重金属为可见光光敏剂, 铁氧化物为 活性中心的稳定高效非均相光 Fenton 催化剂. 此催化剂在制备过程中虽然已经充分利用了市政污泥中的所有成分, 但是 其中部分可生化的有机大分子物质在制备过程中被直接燃烧或碳化, 从而造成能源流失和浪费. 为了更加充分利用市政 污泥中的有机物, 在制备稳定高效催化剂的同时尽可能多地回收能源和资源, 本文在前期研究基础上进行了如下改进和优 化: (1) 采用市政污泥厌氧消化后的消化污泥为载体, 通过厌氧消化手段将其中可生化的有机物转化为沼气, 相对于直接用 市政污泥制备催化剂, 减少了能量流失, 更具有经济效益和环境意义; (2) 通过改变焙烧温度 $(250,350,450,550,650$ 和 $\left.750{ }^{\circ} \mathrm{C}\right)$ 、铁盐类型 $\left(\left(\mathrm{NH}_{4}\right)_{2} \mathrm{Fe}\left(\mathrm{SO}_{4}\right)_{2}, \mathrm{FeSO}_{4}, \mathrm{FeCl}_{3}\right.$ 和 $\left.\mathrm{Fe}\left(\mathrm{NO}_{3}\right)_{3}\right)$ 和铁盐添加量 $(0,0.5,1.0,1.5,2.0$ 和 $3.0 \mathrm{~mol} / \mathrm{L})$ 对所制得催 化材料的性能进行优化.

利用红外光谱、 $X$ 射线衍射、扫描电子显微镜和电感耦合等离子体质谱法等手段对所制备光 Fenton 反应催化剂结构 进行了表征. 结果表明, 以消化污泥为原料制备的催化材料具有多孔和较高的比表面积, 保证了在反应过程中催化剂与 $\mathrm{H}_{2} \mathrm{O}_{2}$ 和被降解物质充分接触. 样品中 $\mathrm{Fe}$ 含量较高, 主要是以 $\alpha-\mathrm{Fe}_{2} \mathrm{O}_{3}$ 或无定形铁化合物形式存在, 并通过 $\mathrm{Si}-\mathrm{O}-\mathrm{Fe}$ 键结合 在污泥载体上, 从而保证了催化剂较多的活性位点和较高的稳定性, 因此所制材料可用作稳定高效的光 Fenton 反应催化 剂.

以偶氮染料罗丹明 $\mathrm{B}$ 为模式污染物评价了所制催化剂对污染物的降解效果. 结果表明, 在焙烧温度和铁盐添加量一定 时, 以亚铁盐 (即 $\left(\mathrm{NH}_{4}\right)_{2} \mathrm{Fe}\left(\mathrm{SO}_{4}\right)_{2}$ 和 $\left.\mathrm{FeSO}_{4}\right)$ 为前驱体所制催化剂性能明显优于以铁盐 $\left(\mathrm{FeCl}_{3}\right.$ 和 $\left.\mathrm{Fe}\left(\mathrm{NO}_{3}\right)_{3}\right)$ 为前驱体的催化 剂; 以 $\left(\mathrm{NH}_{4}\right)_{2} \mathrm{Fe}\left(\mathrm{SO}_{4}\right)_{2}$ 为前驱体且其添加量为 $1 \mathrm{~mol} / \mathrm{L}$, 焙烧温度为 $350{ }^{\circ} \mathrm{C}$ 时所制 FAS-1-350 催化剂具有较高的降解速率 $\left(0.308 \pm 0.016 \mathrm{~min}^{-1}\right)$ 和较低的 $\mathrm{Fe}^{2+}$ 溶出率 $(0.94 \pm 0.24 \mathrm{mg} / \mathrm{L})$. 在紫外光照射下 FAS-1-350 重复使用 6 次, 其催化性能没有 明显降低, 证实该样品结构稳定, 可重复利用, 具有良好的应用前景.

关键词: 消化污泥; 铁基化合物; 介孔材料; 非均相光Fenton反应

收稿日期: 2016-01-13. 接受日期: 2016-02-04. 出版日期: 2016-05-05.

*通讯联系人. 电话: (021)65986297; 电子信箱: daixiaohu@tongji.edu.cn

†共同第一作者.

基金来源：国家科技支撑计划(2014BAL02B02); 国家自然科学基金(51578397).

本文的英文电子版由Elsevier出版社在ScienceDirect上出版(http://www.sciencedirect.com/science/journal/18722067). 